Historic, Archive Document

Do not assume content reflects current scientific knowledge, policies, or practices. 



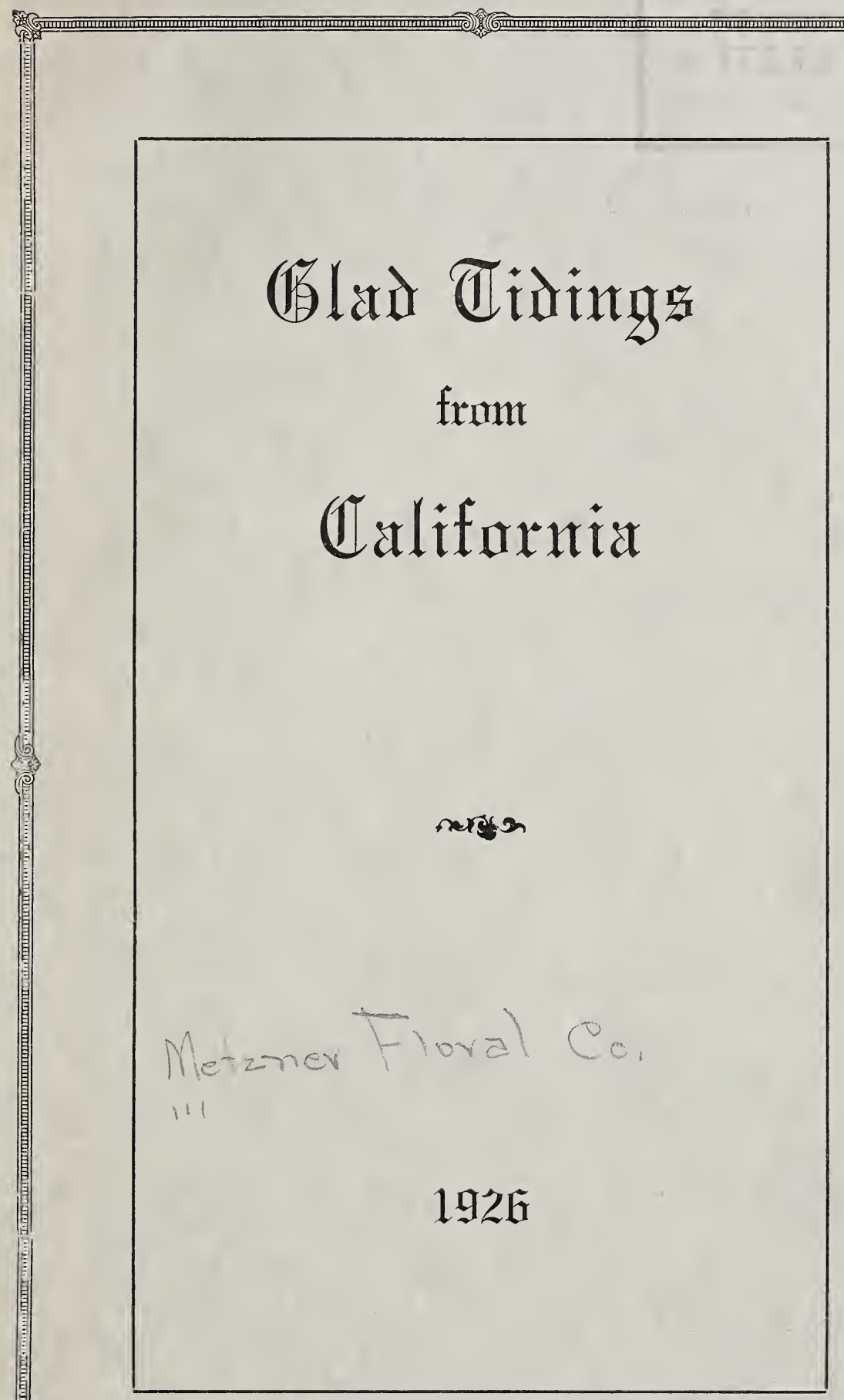





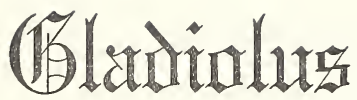

It is our plan, our hope, our purpose, to produce as breeders the very highest type possible in Gladio lus. The work is slow, expensive, and at times quite discouraging; but with a fixed purpose in mind, we press forward, confident that success will crown our efforts, so that the result of each succeeding year's work justifies our motto,

\author{
"WE STILL LEAD"
}

\section{METZNER FLORAL COMPANY}

Mountain View, California

\section{AWARDED THE}

\section{GRAND PRIZE FOR SEEDLING GLADIOLUS}

Panama Pacific International Exposition 


\section{GENERAL INFORMATION}

Our stock in many varieties is limited and we reserve the right to withdraw them from sale without notice.

If for any reason you are not entirely satisfied with your purchase, and you write us in reference to the matter, we will be glad to adjust the complaint to your satisfaction.

We use every reasonable precaution to keep our stock absolutely true to variety. If the variety does not agree with your selection, we will gladly replace such errors with the correct variety, without further cost.

We prepay parcel post and insurance charges to any point in the United States or Canada or foreign countries where the cost is the same.

Terms: Cash. Please remit by Postal or Express Money Order if possible.

Write your name and address, or print it, plainly to avoid mistakes.

Every Gladiolus offered in this catalogue was named by us and is from seed produced and planted on our present premises.

\section{METZNER FLORAL COMPANY}

Mountain View

California, U. S. A. 


\section{PRIZE WINNING GLADIOLUS}

The varieties listed here, all originated on our premises at Mountain View, Santa Clara County, California. Every variety was named by our Mr. Metzner after careful tests showing their respective merits.

Professor Charles E. F. Gersdorff of Washington, D. C., a noted expert on Gladiolus and very generally quoted as an authority by the leading breeders in the United States, gives the following scores in his official tests:

The first numeral indicates the percent value as an Exhibition flower, the second numeral as a Commercial flower. $100 \%$ represents a perfect flower in every detail: Color, size, form, vigor, length of spike and keeping quality. Like humans, none are absolutely perfect, but quite a few of our varieties have tested close to the 100 mark.

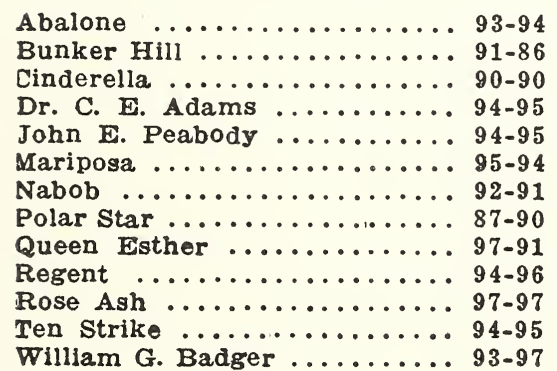

Abalone

Antioch .............. 93-92

Chosen Queen ............ 95-91

Della Thompson .......... 89-88

Fallen Leaf ............. 94-91

Marietta ............. 97-95

Mrs. John S. Wood ........ 97-96

Nellie Grant ............99-89

Psyche ................ 90-91

Redondo ............... 94-93

Rhoda ................ 93-95

Rosenel ................ 94-92

White Dove ............. 97-97

Yellow Prize .............. 93-93

\section{All XXXX Quality}

Professor Gersdorff has only tested a very limited number of our productions. We are confident that our newer and later varieties will all warrant high ratings.

For prices on the above varieties, see quotations in this catalogue. 


\section{NAMED VARIETIES}

\section{Standard Types-No Primulinus}

ABALONE-Light lilac rose, creamy throat, lowers bright yellow sprinkled and edged rose, orchid lip; large blooms, tall spike. Each 50 cents; dozen, $\$ 5.00$.

ACME-Pastel rose, lower petals are sprinkled dark rose over cream. Each 25 cents; dozen $\$ 2.50$.

ADRIAN-Cream white, outer edges of petals tinted bright rose pink; lowers covered wtih solid blotch of bright carmine; round open flower, large size, with tall spike; a good keeper. Late bloomer. Each 20 cents; dozen \$2.00.

ALOHA-Cherry scarlet, throat canary, spotted dark scarlet, tall variety, extra large flower. Each 10 cents; dozen $\$ 1.00$.

ALPINE TREASURE-Light lilac over white ground, brightening to throat; lower petals white; edged deep lilac; orchid type; fine open flower. Each 25 cents; dozen $\$ 2.50$.

ALTA-Cream white, faintly tinged delicate rose; pointed petals. Each 10 cents; dozen $\$ 1.00$.

AMAZON-Blending of cream and flesh pink; large flowers and good spike; tendency to bloom all around the spike at the top. Each 25 cents; dozen $\$ 2.50$.

ANTIOCH-Light salmon, shading to pale orange in throat; tall growing, fine color, large open flower; a general favorite. Each 35 cents; dozen $\$ 3.50$.

ARTIST-Milk white, edged delicate lavender, canary lowers, with faint sprin$\mathrm{kle}$ of lavender and hair line lavender stripes. Each 30 cents; dozen \$3.00.

BAHIA-Bright cherry crimson, lower petals darker shade, strong spike, showy flower. Elach 15 cents; dozen $\$ 1.50$.

BEN LOMOND-Light yellow, with central stripe light garnet. Each 10 cents; dozen, $\$ 1.00$.

BUNKER HILI_-Bright crimson, lower petals heavily covered a bright yellow; fine large flowers; very showy. Each 20 cents; dozen $\$ 2.00$.

CHALIENGE-American beauty pink, lower petals sprinkled cream white. Each 10 cents, dozen $\$ 1.00$.

CINDERELLA-A delicate light rose, the lower petals light primrose; fine bloom and spike; excellent keeper and exquisite under electric light. Each 50 cents; dozen $\$ 5.00$.

COLONIAL-Pale lilac pink, combined with golden yellow; orchid type. Each 25 cents; dozen $\$ 2.50$.

CONSTANCY-Bright rose, very velvety; lowers shade darker, central stripe of purple cast. Each 15 cents; dozen $\$ 1.50$. 
CHOSEN QUEEN-Rose cerise, lighter to throat lower petals solid deep rose, shaded lighter tones to outer edge; very large; splendid type. Each 75 cents; dozen $\$ 7.50$.

DAMON-Light rose pink, cream lowers, with dark red blotch. Each 15 cents; dozen $\$ 1.50$.

DARKNESS-Extra dark garnet, opening buds almost black. We believe this approaches nearest to black of any variety in existence. Each 15 cents; dozen $\$ 1.50$.

DELLA THOMPSON-Pure salmon rose with white central stripe; lower petals and throat pale yellow, faintly sprinkled salmon; very clear color tones; strong tall spike with flowers well spaced; a choice variety. Each $\$ 1.00$.

DELMAR-Light lavender shading to light blue purple, narrow stripe of pale yellow. Each 15 cents; dozen $\$ 1.50$.

DR. FREDERICK J. V. SKIFF-Delicate rose pink, throat and lower petals creamy yellow, overlaid clear rose pink, 5-inch flowers, tall spikes. Bulbs, each 15 cents; dozen $\$ 1.50$.

ERIC LARSON-Light red purple, edged darker tones, bright yellow lowers, with ruby markings and outer edge light clear purple. Each 15 cents; dozen $\$ 1.50$.

ETTA DAVIS-American Beauty pink sprinkled cream white; lower petals marked ruby; flowers five inches and spike six feet tall. Each 15 cents; dozen $\$ 1.50$.

FLORENCE YOUNG-Pure white, tinged delicate lavender, lower petals have solid blotch of dark lavender; fine open flower; slightly ruffled. Each 35 cents; dozen $\$ 3.50$.

FREMONT-Cherry cerise; lower petals sulphur, sprinkled dark cherry. Each 25 cents; dozen $\$ 2.50$.

GARIBALDI-Fiery dark flame orange, lower petals shading almost to black; white throat. Each 15 cents; dozen $\$ 1.50$.

GLORIOUS-Light cerise, shading to pure salmon; well ruffled. Each 25 cents; dozen $\$ 2.50$.

“GOLDEN STATE”-Pale salmon flesh overlaid golden orange; lower petals dark golden yellow with feathering of oriental red. Six to eight open flowers at a time, ranging from 5 to 6 inches in diameter. Spikes 5 to 6 leet tall. Bulbs each 75 cents; dozen $\$ 7.50$.

“GOOD GRACIOUS"--Pale pink blending to clear rose-pink towards the outer edge of petals. Lower petals brilliant rose carmine. Petals are fluted and of thick and leathery texture. Flowers 5 to 6 inches in diameter. Spikes may require staking. Bulbs each 50 cents; dozen $\$ 5.00$.

HARMONT-Light lilac pink, lower petals shading darker, canary stripe. Each 15 cents; dozen $\$ 1.50$. 
"HIGH NOON"-Bright salmon overlaij with flesh pink, lower petals canary gradually shading to a creamy yellow and faintly sprinkled ruby. A central dash of yellow runs almost to the outer edge of each petal. Thin wiry spike four to five feet tall, with flowers $4 \frac{1}{2}$ inches in diameter and usually eight open at a time. A fancy flower for florist trade. Bulbs each $\$ 1.50$; dozen $\$ 15.00$.

IMPERIAL-Light rose cerise, broad open flower on strong spike. Each 25 cents; dozen $\$ 2.50$.

INVINCIBLE-Lilac pink, shaded lighter to throat, lower petals straw with feather of bright ruby. Each 25 cents; dozen $\$ 2.50$.

JOHN E. PEABODY-Dark rose pink, or rather a light American beauty; very large open flower, well placed and spikes over five feet tall; much admired in our trial ground. Each 75 cents; dozen $\$ 7.50$.

JUANITA-White tinted pink, lower petals nelrose; very large flower; grand spike. Each 50 cents; dozen $\$ 5.00$.

LARKSPUR-Brilliant scarlet rose with central stripe of white in all petals; lower petals covered with flame scarlet over white ground. Each 25 cents; dozen $\$ 2.50$.

LINDA-Cream with brilliant carmine blotch; fine large flowers, many open; tall spikes. Each 50 cents; dozen $\$ 5.00$.

MAGNOLIA-Lemon white, with crimson marking; fine spike. Each 25 cents; dozen $\$ 2.50$.

MARIPOSA-Buttercup yellow, tinted delicate rose; lower petals mandarin orange blotch; heavy foliage, tall spike, fine flower. Each 50 cents; dozen $\$ 5.00$.

MASCOT-Wine, shading to dark maroon; lower petals creamy yellow; covered garnet. Each 25 cents; dozen $\$ 2.50$.

NABOB-Light cerise scarlet on outer edges shading to flesh tone in throat; lowers covered cream white, with central stripe cream in all petals; large open flowers and fine spike with side laterals. Each $\$ 1.00$.

NELLIE GRANT-A dark nelrose or American beauty crimson, shading lighter to throat; central stripe of garnet on lower petals; very rich color tones and velvety; short, round form of petals; large open flowers and tall spike; admired whever shown. Each 30 cents; dozen $\$ 3.00$.

NORA WILSON-Cream white overlaid and edged pale rose pink; lower petals darker self tones and dark rose pink covering; gooj type and tall spike. Each 25 cents; dozen $\$ 2.50$.

OCTAVIA-Pastel or old pink, shaded old gold and cardinal. Each 10 cents; dozen $\$ 1.00$.

ORIENTAL BEAUTY-Rose cerise tinged old rose, flaked dark burnt orange and steel blue; lower petals light sulphur, spottel rose ruby. Each 25 cents; dozen $\$ 2.50$.

ORION-Good scarlet, shaded cardinal to throat; excellent variety. Each 10 cents; dozen $\$ 1.00$. 
"OROSI"-A ruffle orange flame, lower petals dark orange with cardinal stripe, and lightly sprinkled white. A vigorous grower, with side laterals and heavily ruffled. Flowers $4 \frac{1 / 2}{2}$ inches in diameter and extra tall spikes. Bulbs each $\$ 1.00$.

PASSION FLOWER-Pure cardinal with sprinkling of white in throat; lower petals covered dark garnet. Each 15 cents; dozen $\$ 1.50$.

PEERLESS-Pale lavender pink over white ground; lower petals covered with solid feather of light purple. Ruffled, six open flowers five inches in diameter; very tall. Each 25 cents; dozen $\$ 2.50$.

PENNANT-Cherry scarlet, very rich-velvety color tone; faint touch of white in throat. Each 15 cents; dozen $\$ 1.50$.

POLAR STAR-The only white variety receiving a Gold Medal at the P. P. I. E. This variety was officially recorded under this name, was never known under any other name and the award of a Gold Medal given to Metzner Floral Co., of Mountain View, California, owners of the exhibit. Bulbs, 25 cents each; $\$ 2.50$ per dozen.

PSYCHE-Light salmon rose; always admired; a veritable orchid. Each 25 cents; dozen $\$ 2.50$.

"PURITAN GIRL"-Pearl white, edged lavender, lower petals covered with a heavy blotch of dark ruby purple. Flowers $4 \frac{1}{2}$ inches in diameter, spikes 4 to 5 feet tall. Bulbs each $\$ 1.00$.

QUEEN ESTHER-Brilliant red purple, shading darker to outer edges; lower petals covered with gold and sprinkled purple; five-inch blooms; six to eight open at a time; strong spikes five to six feet tall. Each $\$ 1.00$.

RAGTEN-Light garnet, lower petals shaded dark garnet, creamy throat, blue purple marking. Each 10 cents; dozen $\$ 1.00$.

RED COAT-Showy combination of bright scarlet upper and bright yellow lower petals. Each 10 cents; dozen $\$ 1.00$.

REGENT-Lemon white, tinged bright rose pink on outer edge of petals, lowers pale primrose, with brilliant rose pink blotch, large flower, well placed, fine spike with side laterals, heavily ruffled. Each $\$ 1.00$.

RHODA-Salmon, slightly flaked darker self tones; always admired. Each 25 cents; dozen $\$ 2.50$.

RIALTO-Light pink with dark cherry cerise in every petal; very large flower; vigorous spike. Each 25 cents; dozen $\$ 2.50$.

ROSENEL_Clear nelrose, lower petals garnet; rare color tones. Each 25 cents; dozen $\$ 2.50$.

SALMO-Medium shade of salmon, turning to darker self tones; large open flower. Fach 15 cents; dozen $\$ 1.50$.

SCOTLAND-Ivory white, lower petals deep cream; solid blotch of ruby; heavily ruffled; fine form and color. Each 25 cents; dozen $\$ 2.50$.

SELECTION-White ground, edges tipped lavender; star type; large flower, fine coloring. Each 50 cents; dozen $\$ 5.00$. 
SEMINOLE-Bright cherry scarlet; cream throat; a splendi.j variety. Each 15 cents; dozen $\$ 1.50$.

SILVER MOON-Milk white; has many admîrers. Each 15 cents; dozen $\$ 1.50$.

SIRIUS-Light flesh pink, lower petals dark cream, overlaid with blotch of brilliant cherry; tall spike. Each 10 cents; dozen $\$ 1.50$.

"SOUTHERN SKIES"-Light crushed strawberry, flaked and splashed a delicate old rose, lighter to throat; lower petals clear canary edged old rose, orchid type; lower petals turn back tightly. Flowers $4 \frac{1}{2}$ inches in diameter with eight open flowers showing at a time; tall flower spike. A very attractive flower. Bulbs each $\$ 2.00$; dozen $\$ 20.00$.

SUMMER DREAM-Light American beauty pink, shading to white in the throat; lower petals white, edged rose pink. Each 50 cents; dozen $\$ 5.00$.

TEN STRIKE-Salmon pink, lower petals bright scarlet edging over canary; extra good. Each 25 cents; dozen $\$ 2.50$.

THE PILOT-A rose blende $\lambda$ white, ruffled. Each 25 cents; dozen $\$ 2.50$.

TOKAY-Blended cerise, shading to almost scarlet from very light cerise; large flower; short spike; ideal for border. Each 5 cents; dozen 50 cents.

TWILIGHT-Cream white, pointed petals, narrow stripe of pink on lower petals. Eiach 15 cents; dozen $\$ 1.50$.

"WHITE DOVE"--Milk white, with very faint tinge of pale primrose on lower petals. Short feather of delicate lavender. Very tall vigorous spikes and usually with several laterals. Round petals, fine open flower of good form and extra large size. A combination exhibition and florist type. Bulbs each $\$ 3.00$; dozen $\$ 30.00$.

"WHITE ROSE"-Lemon white, lower petals primrose with very narrow cardinal stripe. The petals are of unusual form, are round and of equal length, curling around each other as they open, presenting the appearance of an opening rosebud. Flowers of good size and long spike. We believe this may be the forerunner of a new type. Bulbs each 50 cents.

YELLOW PRIZE--Bright canary; lower petals rich golden yellow; very clear color tones throughout; good spike; flowers well placed. Each 35 cents; dozen $\$ 3.50$.

YELLOW JACKET-Light canary yellow, with lower petals of golden yellow. Each 10 cents; dozen $\$ 1.00$.

YOLO-Extra large flower of bright cerise, shading to scarlet; lower petals tinted cream and overlaid with cardinal spot. Each 35 cents; dozen $\$ 3.50$.

YOSEMITE-Rich salmon rose, well ruffled; a choice variety. Each 20 cents; dozen $\$ 2.00$.

ZEPHYR'S GIFT-Light rose pink over white ground; outer half of petals shading to a dark royal rose pink; lower petals very velvety, of deep rose pink, with central stripe of maroon; round shape petals; large flower. Each 50 cents; dozen $\$ 5.00$. 


\section{Our Introductions of 1925}

AMBER JEWEL-Copper red blending to garnet, self-tones; very attractive; good open flowers. Each $\$ 1.00$.

BETHANY-Cream white, tinged pale pink, bright carmine blotch on lower petals; elght open flowers on splendid spike. Each $\$ 2.00$.

BLUE JACKET-Rich purple, lower petals deep blue purple; large wide open flowers, tall vigorous spikes. Each $\$ 2.00$.

CABERNET-A blending of maroon and blue purple, making a rich tone of wine color. Exceptionally large flowers, well placed an 3 many open; extra tall spikes. Each $\$ 7.50$.

COPPER QUEEN-A wonderful blending of old rose and bright copper. Rich new color tints; wide open flowers 6 inches in diameter well placed on a tall graceful spike. Each $\$ 10.00$.

FLAMBEAU-Brilliant flaming scarlet, solid color tones, very heavily ruffed; broad open flowers, strong tall spikes. An attractive color. Each $\$ 1.00$.

GRANADA-Crushed strawberry blending with dark pomegranate; lower petals sulphur spotted pomegranate, with a coppery tinge. Large open flowers, tall spikes with side laterals. Each $\$ 2.00$.

MADRONE-Bright rose-pink, solid tones, large wide open flowers, tall spike. Each $\$ 1.00$.

MANZANITA-Steel blue overlaid light plum, stripe of pomegranate in center of each petal; lower petals tinged ruby; large flowers on strong spike. A good novelty. Each $\$ 1.00$.

MECCA-Light lilac blending to clear lavender; lower petals pale yellow, edged rich cattleya purple; orchid type. Each $\$ 1.50$.

MORENA-Pastel lavender, shading to lilac; lower petals covered deep royal crimson, heavily ruffled; spikes 5 feet tall. Each $\$ 3.00$.

ROMANTIC-Pale flesh, shaded salmon rose and splashed pure orange; lower petals orange with ruby marking, fluted edges; six or more wide open flowers on tall strong spikes. Each $\$ 3.00$.

ROSENA-Bright rose, lower petals clear soft tones of a deeper shade, central stripe of canary, no other markings; graceful spikes. Good commercial type. $\$ 3.00$.

ROYAL CROWN-Clear lilac shading to cattleya purple, lower petals circled deeper cattleya purple and brightened with a short narrow dash of white. Extra tall wiry spikes. Each $\$ 5.00$.

SHASTA-Clear copper red, lower petals shading to cardinal; round open flowers on a good straight spike. Each $\$ 1.00$. 


\section{A Page of Prize Winners Everywhere}

\section{MARTETTA}

A delicate shade of light salmon, beautifully blended with light orange, the lower petals shading to a bright burnt orange. A marvelous Gladiolus of extra large size and splendid spike. Always admired, in great demand.

This beauty is rated by the eminent Gladiolus expert Mr. Chas. E. F. Gersdorff, as follows: Exhibition 97 per cent, Commercial 95 per cent out of a possible 100 .

We believe his judgment is endorsed by every one who has purchased Marietta. Large bulbs, each 50 cents; dozen $\$ 5.00$.

\section{MORS. JOHIN S. WOOD}

A wonder flower, easily six inches in diameter with spikes six feet tall. The open flowers, six or more at a time, are perfectly placed.

The color is a brilliant coral, the lower petals gradually blending from.salmon into a scarlet tone, mingled with sulphur.

This Gladiolus is now grown in many foreign lands and throughout the United States. All who have seen it praise its beauty. The demand is greatly in excess of the supply. A grand exhibition flower. Large bulbs each $\$ 1.50$; dozen $\$ 15.00$.

\section{ROSE ASH}

Our original introduction and named by our Mr. Metzner. A general favorite in the United States and many foreign lands. First listed in our catalogue in 1916, it has by reason of its high standard of quality and beauty of color, caught the public eye, and no collection of Gladiolus, large or small, is complete without it.

ROSE ASH-An exquisite blending of light old rose and ashes of roses, lightened up in the throat with a golden tinge; fine formation, ruffled and fluted petals. Like a magnet, sure to attract; tall sturdy spikes, straight as an arrow. Large bulbs each 20 cents; dozen $\$ 2.00$.

\section{STANFORD}

This wonderful Gladiolus, a pure lark cardinal splashed with black and covered with a velvety sheen that glistens like the sparkling dew, added to its great size-six inches in diameter, was named, by reason of its admiration by one of the faculty, in honor of California's grand university, Stanford, and its founder Leland Stanford. This university at Palo Alto is in Santa Clara County, close to our location at Mountain View, Santa Clara Co., the birthplace of this grand flower. Bulbs each $\$ 2.00$.

\section{WHIIIAM G. BADGFAR}

This glorious flower first offered by us in 1923 has met with universal favor wherever shown. The color is a delicate coral, edged with darker coral tones; throat pale yellow, sprinkled dark coral on the lower petals. The flowers, six to eight open at a time, are six inches in diameter, perfect in placement, on spikes five to six feet high.

A beauty in every respect, a sure winner everywhere. Large bulbs each $\$ 2.50$; dozen $\$ 25.00$.

\section{FALLEN LEAF}

Dark old rose, tinted ashes of roses; lower petals, blending of light woodbrown and old rose. Grand color novelty. Fine formation. $\$ 2.50$ each. 


\section{New Introductions for 1926}

ALICE EASTWOOD-A true cerise or velvety cherry, upper petals deep rose cherry with a faint purple stripe showing; a light flaking of dark orange adds to the richness of color tone. Lower petals covered with a ruby crimson faintly edged with cream white. Spikes 4 to 5 feet tall, with six or more flowers open at a time and five inches in diameter. An exceptionally fine variety. Named by request as a compliment to Miss Alice Eastwood, a California botanist of high standing. Price $\$ 5.00$ each.

BOLD WARRIOR-Milk white, lightly tinged lavender on the extreme edge of petals; lips light canary with feathering of ruby. A ruffled variety. Five-inch flowers on a tall spike, vigorous habit. Large bulbs each $\$ 2.00$.

DIRIGO-Bright scarlet shading to darker tones on the outer edges; lower petals creamy yellow, overlaid with rich cardinal. Large flowers, six open at a time, tall, straight spike. A seedling out of Bunker Hill, of equal vigor, but of a decided red. Large bulbs each $\$ 1.00$.

DR. C. E. ADAMS-Pure white, faintly tinged with pale rose lavender on the outer edge of petals. Throat almost a pure white with a very faint tinge of pale primrose running out to pale pink; rich as an orchid. Large flowers on a tall spike, well placed with six or more open flowers at a time makes this gladiolus a beauty for exhibition or florist's use. Named in honor of a true gladiolus fan, an enthusiastic flower lover, and one of the leading workers in the Flower Lovers' Club of San Jose, California, noted for its regular exhibitions, always free to the public. Large bulbs each $\$ 5.00$.

GIANT PANSY-A clear, light mauve overlaid with a heavy blotch of dark, velvety mauve on the lower petals. A fine large flower well placed on a tall, straight spike with many open flowers at a time. This is one of our "Try Out" gladiolus and well named by an eastern admirer. Bulbs each $\$ 3.00$.

MINERVA-Light lavender pink with central stripe of cream white; lower petals; cream with a short feather of dark purple. Large flower and fine placement on a good spike, six or more open. Buibs each $\$ 1.00$.

MODOC-Dark cherry scarlet with cardinal markings on lower petals; broad open flowers on a tall spike. A bright showy rea. Bulbs each 50 cents.

REDONDO-Rich dark red, overlaid with clear garnet blotch over white ground on lower petals. Large flowers, six open at a time, well placed on a fine spike. Bulbs each $\$ 1.00$.

SEA GULL-Milk white, the lower petals tinged with golden yellow overlaid with a faint touch of ruby. Broad open flowers, five inches in diameter with six or more open at a time. Tall, strong spike. A vigorous seedling out of Polar Star. Bulbs each $\$ 1.00$.

SUNKIST-A wonderful shade of clear, bright, golden orange, lightly touched with orange flame on the lower petals; very large broad open flowers on a splendid spike. A seeāling out of Marietta and of exceptional beauty. Bulbs each $\$ 10.00$.

HEART'S DELIGHT-Owing to the limited reproduction of this variety, we will hold its introduction until another season and we request that "Try Out" buyers of this variety ( $N / 124)$ do likewise. 


\section{SPECIAL COMBINATION SETS}

We have arranged in collections for the convenience of buyers, select bulbs covering a broad range of colors and at a liberal price reduction. Large bulbs, sure to bloom. Please order these sets by name heading the list.

\section{ADRIAN SET}

\begin{tabular}{|c|c|c|}
\hline Adrian .. & $\ldots \ldots \ldots$ & 0.20 \\
\hline Bahia ... & $\ldots \ldots \ldots$ & .15 \\
\hline Challenge & $e \ldots \ldots$ & .10 \\
\hline Cinderella & $a \ldots .$. & .50 \\
\hline Darkness & $\ldots \ldots$ & .15 \\
\hline Delmar. & $\ldots \ldots \ldots$ & .15 \\
\hline Harmony & $\ldots \ldots$ & .15 \\
\hline Mascot & $\ldots \ldots \ldots$ & .25 \\
\hline Ragten . & $\ldots \ldots \ldots$ & .10 \\
\hline Yosemite & $\ldots \ldots$ & .20 \\
\hline
\end{tabular}

Special Price, $\$ \mathbb{1 . 5 0}$

\section{AMAZON SET}

Amazon ....... .25

Alpine Treasure . .25

Flambeau ...... 1.00

Good Gracious .. .50

Linda ........ .50

Nellie Grant .... . .30

Peerless ....... .25

Psyche ..................... 15

Redondo ....... 1.00

Southern Skies ... 2.00

Total Value ....\$6.30

Special Price, \$5.00
BUNKER HUL SEI

Bunker Hill ....\$0.20

Colonial ....... .25

Constancy ...... .15

Florence Young .. . .35

Magnolia ....... .25

Mariposa ...... . .50

Mascot ..........25

John E. Peabody. .75

Rhoda ..................

Rosenel ........... .25

Total Value ...\$3.20

Special Price, \$2.50

\section{AMBER JEWEL}

\begin{tabular}{|c|c|c|}
\hline Amber Jew & ... & \\
\hline Blue Jacket & $\ldots \ldots$ & 2.0 \\
\hline Chosen Quee & $n \ldots$ & .7 \\
\hline Good Gracio & us ... & .0 \\
\hline John E. Pea & body. & \\
\hline Iarietta ... & $\ldots \ldots$ & .0 \\
\hline Orosi $\ldots .$. & $\ldots \ldots$ & 1.0 \\
\hline election ... & & .5 \\
\hline hasta ... & $\ldots \ldots$ & 1.0 \\
\hline White Rose & $\ldots \ldots$ & .5 \\
\hline $\mathrm{Va}$ & $\cdots$ & \\
\hline & e, $\$$ & \\
\hline
\end{tabular}

Blue Jacket ....2 2.00

Chosen Queen ... .75

Good Gracious ... $\quad .50$

1.00

Selection ...... .50

Shasta ....... 1.00

.50

Special Price, $\$ \mathbf{7 . 0 0}$

ABALONE SET

\begin{abstract}
Abalone ......\$0.50
Artist ........ .30

Marietta ...... .50

Nabob ....... 1.00

Polar Star ...... .25

Puritan ....... $\quad .50$

Summer Dream .. $\quad .50$

Ten Strike ...... .25

The Pilot ...... .25

Zephyr's Gift .... .50

Total Value ...\$4.55

Special Price, $\$ 3.50$
\end{abstract}

\section{FLAMBBAU SET}

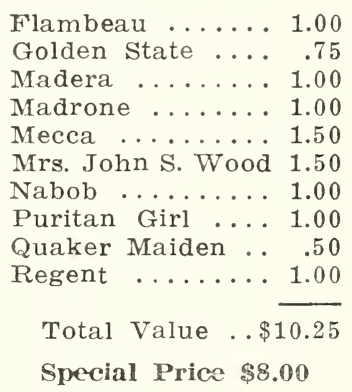

Golden State ... .75

Madera ....... 1.00

Madrone ....... 1.00

Nabob a.

Puritan Girl .... 1.00

Quaker Maiden .. .50

Regent ...... 1.00

Special Price $\$ 8.0$
Total Value ..\$10.25

A combined collection of the above six sets for.

\section{THE EASTWOOD SET}

Alice Eastwood ..........\$5.00

Blue Jacket .............. 2.00

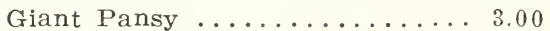

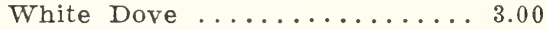

William G. Badger ........ 2.50

Total Value .......... $\overline{\$ 15.50}$

Special Price \$12.00

\section{THE COPPER QUEEN SET}

Copper Queen .........\$10.00

Dr. C. E. Adams .......... 5.00

Fallen Leaf .............. 2.50

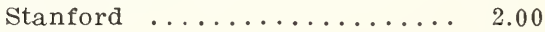

Sunkist ............. 10.00

Total Value ......... $\overline{\$ 29.50}$

Special Price $\$ 25.00$

One each Eastwood and Copper Queen Sets ...............\$35.00

Or one set each in medium size bulbs...................\$\$20.00 


\section{SPECIAL "TRY OUT" GLADIOLUS}

In our breeding work for new and improved varieties, we set aside for further testing, many that show merit or promise of superiority. Before naming them and offering them to the General Public we prefer to have a more general expression as to their merits and plan to get written reports from growers in different climates and in other soil.

Based on these reports many are discarded from our prospective lists and only a limited number that show unusual merit are retained.

Try out buyers only, are advised of the names assigned to these new varieties and have the advantage of increasing their own holdings prior to listing in our catalogue.

No variety is listed at less than the original price and quite a few command a fancy figure, with profit to the original buyer. In response to the numerous enquiries asking whether we will again offer these Try Out bulbs for 1926, we have decided to set aside about 50 promising varieties this season for this purpose. The supply is limited. Not over 10 supplied to any one purchaser. The price is uniform to all $\$ 1.00$ each.

You have a chance for possessing, for a nominal sum, a Gladiolus that some noted specialists would name and catalogue, adding one or more ciphers to our price. We expect in return written reports of your test. All at $\$ 1.00$ each, large size. 


\section{EXTRA SPECIAL ADVERTISING OFFER}

Every season some named varieties are mixed in curing and handling; we also find in our new seed beds, varieties that are not distinctive enough or too close to named varieties, but still very attractive and worthy of continuation. We offer these for advertising purposes at a nominal price far below their intrinsic value, as our,

\section{DOLLAR LIMIT SETS}

One dozen No. 1 size bulbs for $\$ 1.00$

or

Two dozen Planting size for.

We have set aside for this purpose 6 sets or 72 varieties in all for a total of $\$ 5.00$

A complete set would give you 72 distinctive colors. No two sets alike. Order what you want.

Try one of these combined sets. You will have a garden of beauty when they bloom. These sets are not labeled as to name, but the values of some will range from $25 \mathrm{c}$ to $\$ 1.00$ each. In ordering state distinctly Large Bulbs or Planting Size. Unless so stated we invariably send large bulbs.

\section{FLOWER CLUBS - FREE BULBS}

Regularly organized Flower Clubs will receive free of cost, choice Gladiolus Bulbs for distribution to their members, prorided a list of names with their addresses, certified by the President and Secretary, is received by us before April 5th, 1926. 


\section{SEED SURE TO GIVE SATISFACTION}

We offer a limited amount of choice seed in flowers, of which we make a specialty, and have been grading to a high standard.

\section{GRAND PRIZE STRAIN GLADIOLUS}

Our own development and standard types oniy.

Seedling Bed mixture, per pkt..................... $\$ .50$

Private Stock, hand crossed, per pkt........................ 1.00

\section{GERANIUM SEED}

We believe we have the best strain in cultivation. During the past few years we have developed some beautiful new colors of extra large flowers with massive trusses. The colors are clear and held on long stems.

Seed sure to germinate, per pkt................... 50

\section{GAILIARDIAS}

Our strain of this perennial shows a remarkable improvement in size of flower, lenghth of stem and in new and beautiful color combinations.

"Golden West" a pure yellow throughout, pkt............. .25

Giant Grandifloras, new and bright colors, pkt............ .25

\section{GERBERA OR TRANSVAAL DAISIES}

We have been working on this wonderful cut flower for several years with success, and have over 40 distinctive colors.

We offer fresh seed, per pkt....................... 50 


\section{ARE YOU IN DOUBT WHAT TO ORDER?}

Why not trust to our judgement. Just indicate the amount of moner you Wish to spend and let your order read:

"Send 1 doz. bulbs best ralue for $\$ 1.00$ " or

"Send 1 doz. bulbs best value for \$20.00."

or order any intermediate amount. We feel confident you will be fully satisfled with your purchase.

\section{GRAND PRIZE MIXTURE} Mixture

Iou mas prefer named varieties, but we ask a trial of our Grand Prize

Out of our seedlings each season, we reserve for further test, a rery limited number of bulbs and these must be of large size, good formation and choice colors, certain to grade orer 90 per cent or XXXX in quality.

If you grow cut flowers for the market you will find mant gems worth saving in this mixture and rarely two alike.

Price $\$ 5.00$ per 100 or $\$ 40,00$ per 1000 .

Planting stock at one-half the abore prices.

We prepas delivery charges.

\section{MOUNTAIN VIEW MIXTURE}

A splenjid mixture made up of selected rarieties, but unnamed; colors too close to our existing rarieties and named types that become mixed in handling. We also include some of our earlier named varieties which we plan to discontinue. Our purpose is to steadily improve our standard of qualits.

This mixture is Wonderful value at price quoted.

$\$ 3.00$ per hundred or $\$ 25.00$ per 1000 .

Planting size at one-half the abore quotations.

\section{ARE YOU INTERESTED IN FLOWERS}

"The Flower Grower," published monthly by Madison Cooper, Calcium, New Fork, is full of interesting matter regarding flowers in general. Price $\$ 2.00$ a year.

\section{DO YOU ADMIRE THE GLADIOLUS}

Fou should join the American Gladiolus Society and receive their monthly bulletin.

Cost is $\$ 2.00$ a rear. Remit airect to John C. Davis, Secretary, it South Avenue, Rochester, New Fork.

\section{METZNER FLORAL COMPANY \\ Mountain View, \\ Santa Clara County \\ California}


California

佰ladiolut 